\title{
Review of Joost Hengstmengel's Divine Providence in Early Modern Economic Thought. New York, NY: Routledge, 2019, 248 pp.
}

\author{
PAUL OSLINGTON \\ Alphacrucis College
}

This book is the product of many years of research by Joost Hengstmengel on the role of divine providence in the early modern history of economics, and is based on his doctoral thesis "Divine Oeconomy: The Role of Providence in Early-Modern Economic Thought before Adam Smith" completed at the Erasmus Institute for Philosophy and Economics in 2015.

A brief introductory chapter 1 sets out the aims and scope of the book. The central question is "how ideas about providence were reflected in thinking about the economy" (44). Hengstmengel writes that he will cover the early modern discussions but the contemporary influence of the doctrine of providence (for example, as explored by Thorstein Veblen or the late Robert Nelson) is outside his scope. There is a brief discussion of how providence relates to debates about the secularization of economic thought but resolving this question is also outside the scope of the book. Jacob Viner's (1977) work on providentialism was a major stimulus for his research program but Hengstmengel does not always follow Viner's view, and Viner's focus was the eighteenth century together with the role of providentialism in earlier theories of trade. There has been other work on the eighteenth and nineteenth centuries (for instance, by Anthony Waterman 1991, 2004), including my own work (Oslington 2018), but less on seventeenth-century economic writers, leaving a gap which Hengstmengel fills well.

Chapter 2 is a general overview and history of the idea of divine providence, and the related idea of natural theology. One of the aims of the chapter is to establish a canonical version of the doctrine of providence in sixteenth-century European Christianity, as a fixed point for Hengstmengel to work from in the remainder of the book. The doctrine of providence has the following elements: (1) God not only created the world but also sustains it. (2) Divine providence extends to all beings, 
things, and events. (3) Divine providence leaves no room for chance, fortune, and fate. (4) There is both general and special providence, ranging from general care of the world and of mankind to special care of the church. There is also a distinction between ordinary providence in the regular nature of the world and extraordinary providential acts. (5) The workings of God's providence are partly hidden to man. (6) God sometimes allows evil, but is in no way responsible for it. (7) God's providence is particularly concerned with the spiritual wellbeing of man (23-25). After establishing this fixed point, Hengstmengel goes on to note several post-Enlightenment transformations of providence discussed by other recent writers, including Charles Taylor (2007) and Stephen Gaukroger (2016). These include the naturalization of providence where a personal architect is replaced by impersonal laws, the related demystification of providence, the tendency towards an optimistic providentialism tied up with ideas of progress, an anthropocentric shift where providence becomes about man's happiness, and dormant providence where we are yet to see the results of divine planning (27-30).

After this general material, the book moves to consider a succession of topics in economics which relate to providence. Chapter 3 is entitled "International trade: God's universal economy"; chapter 4 is on "Division of labour: the divine ordering of society"; chapter 5 on "Value and price: a providential abundance of necessities"; chapter 6 on "Self-interest: the invisible hand of God"; and chapter 7 which covers "Poverty and inequality: rich and poor God-willed". Chapter 8 concludes.

The discussion is detailed, careful, and much of it based on primary sources. An example is on page 57 where the doctrine of universal economy from the secondary literature is traced back to a portion of Jacques Savary's 1675 work Parfait Négociant on commerce and the plan of God. Hengstmengel quotes a translation of Savary's work:

From the manner in which the Providence of God has disposed the goods on the earth, one well sees that he wanted to establish unity and charity among all men, for it imposed on them a kind of necessity to be always in need of others. He did not want everything that is necessary in life to be found in one single place, he scattered his gifts, so that men would trade together, \& that the mutual necessity which they have to help one another could sustain the friendship between them: it is this continual exchange of all the convenience of life that constitutes commerce. (57) 
And then methodically considers how the ideas in the quotation permeate economic writing over the next century. There is an excursus on classical precursors of the idea, which considers Plato, Seneca, Virgil, and then the fourth-century writer Libanius of Antioch. Viner (1978) also had identified Libanius as a key figure for the universal economy doctrine but was less precise than Hengstmengel about the relevant texts, leading to some confusion in the literature.

Hengstmengel largely confines himself to a selection of topics that have already received attention in the literature. These range from the initial chapter on Viner's (1937) early interest, international trade; to the chapter on the much-discussed invisible hand which utilises Albert O. Hirschman's (1977) grid of economists' responses to Hobbes-Mandeville; and the final topical chapter on the Hume-Tucker rich country/poor country debate which has been extensively covered by István Hont (2005). The overall conclusion of the book is that most of the features of the early modern theological discussion of providence can be found in the economic writings of the period (202). This is not to say though that the lack of topical innovation or grand claims means Hengstmengel's discussion lacks accuracy or insight.

A limitation of the book is its emphasis on a sixteenth-century Reformed account of providence. It is true that much early economic writing was in this context, preeminently the economic writing of Enlightenment Scots, but a lot was not. The Neapolitan writers, whom Hengstmengel devotes quite a bit of space to, operated in a very different Catholic intellectual environment. As did the many of the English Enlightenment writers. Boisguilbert as a Jansenist is a fascinating borderline case, as previously discussed by Gilbert Faccarello (1999). The point is that the canonical version of divine providence set out in chapter 1 fits some economic writers Hengstmengel considers better than others. Even within Reformed Christian theology there is variation, as standard recent treatments of Mark Elliott (2012, 2015) and David Fergusson (2018) make clear. Taking into account all the variations in the doctrine of providence across traditions over several centuries would make a book like this impossible to write, and I can understand the decision to work from a single portrait of providence to the economic writings. However, a bit more flexibility would have made for a stronger history of the interrelationships between the doctrine of providence and economic thought. It would also have allowed for more consideration of the feedback-influence of economic thinking on theology. 
The book succeeds in analysing the content of ideas, but pays less attention to the other levels of analysis that Hengstmengel enumerates in his concluding chapter: the language and style of arguments, and the way that theological ideas functioned politically in the economic writings discussed. The standard for these other levels of analysis remains the history of science work of John Hedley Brooke (1991) and Peter Harrison (2015), admittedly a standard that pretty well all of us in the history of economics fall short of.

Much work remains to be done, as Hengstmengel notes, on the "afterlife of early modern economic providentialism" (206) but this is a valuable book on an important topic, and one that I learnt much from. It will be especially valuable to historians of economics who lack training in theology which is necessary to come to grips with writings that emerged from the theology-soaked intellectual culture of the seventeenth and eighteenth centuries. No other work is as comprehensive and clear on the topics it covers. I look forward to reading the products of the next stages of Hengstmengel's research program.

\section{REFERENCES}

Brooke, John H. 1991. Science and Religion: Some Historical Perspectives. New York, NY: Cambridge University Press.

Elliott, Mark W. 2012. The Heart of Biblical Theology: Providence Experienced. Aldershot: Ashgate.

Elliott, Mark W. 2015. Providence Perceived: Divine Action from a Human Point of View. Berlin: De Gruyter.

Fergusson, David. 2018. The Providence of God: A Polyphonic Approach. New York, NY: Cambridge University Press.

Faccarello, Gilbert. 1999. The Foundations of 'Laissez-Faire': The Economics of Pierre de Boisguilbert. London: Routledge.

Gaukroger, Stephen. 2016. The Natural and the Human: Science and the Shaping of Modernity, 1739-1841. Oxford: Oxford University Press.

Harrison, Peter. 2015. The Territories of Science and Religion. Chicago, IL: University of Chicago Press.

Hirschman, Albert O. 1977. The Passions and the Interests: Political Arguments for Capitalism before Its Triumph. Princeton, NJ: Princeton University Press.

Hont, István. 2005. Jealousy of Trade: International Competition and the Nation State in Historical Perspective. Cambridge, MA: Belknap Press.

Oslington, Paul. 2018. Political Economy as Natural Theology: Smith, Malthus and Their Followers. London: Routledge.

Savary, Jacques. 1675. Le Parfait Négociant. Paris: Louis Billaine.

Taylor, Charles. 2007. A Secular Age. Cambridge, MA: Belknap Press. 
Viner, Jacob. 1937. Studies in the Theory of International Trade. London: Allen and Unwin.

Viner, Jacob. 1977. The Role of Providence in the Social Order. Princeton, NJ: Princeton University Press.

Viner, Jacob. 1978. "Religious Thought and Economic Society: Four Chapters of an Unfinished Work." History of Political Economy 10 (1): 9-189.

Waterman, Anthony M. C. 1991. Revolution, Economics and Religion: Christian Political Economy, 1798-1833. New York, NY: Cambridge University Press.

Waterman, Anthony M. C. 2004. Political Economy and Christian Theology since the Enlightenment: Essays in Intellectual History. New York, NY: Palgrave Macmillan.

Paul Oslington is Professor of Economics and Theology at Alphacrucis College, the national college of the Pentecostal movement in Australia. His $\mathrm{PhD}$ in Economics and Master of Economics/Econometrics with Honours were completed at the University of Sydney, and his Bachelor of Divinity and Doctor of Theology through University of Divinity, Melbourne. His books include The Theory of International Trade and Unemployment, Adam Smith as Theologian, The Oxford Handbook of Economics and Christianity, Political Economy as Natural Theology: Smith Malthus and their Followers and he is currently working on a monograph commissioned by Harvard University Press, God and Economic Order.

Contact e-mail: <paul.oslington@ac.edu.au> 